\title{
Discourse Analysis of Allah's Conversations with His Creatures in the Holy Qura'an
}

\section{ABSTRACT:}

*Dr. Syed Shujaat Ali

*:Dr. Syed Bacha Agha

Linguistics, through discourses analysis, offers us guidelines for holding successful conversation by following some principles. It guides us about the strategies on when and how to slip into conversation and what type of qualities should we have in our responses to be cooperative in conversation. Qura'an, being the book of guidance by our Creator, also tenders some exquisite models of conversation from the analyses of which some useful rules of successful conversation can be deduced. Some of the dialogues that Allah held with His creatures find mention in the Holy Qura'an. The purpose of these dialogues with the creatures is their well-being and reformation and at the same time they serve as superb models of guidance, insight and high standard of morality. Along with these conversations, there are some verses in the Holy Qura'an where Allah gives us explicit guidelines for conversation. Analyses of conversations of Allah with the angels, Satan, and the prophets like Ibrahim, Noah, Musa, and Mohammad (mpbh) were carried out with the supporting guidelines of conversation from the Allah in the Holy Qura'an. In these conversations we find, apart from the generally known Gricean maxims of cooperation, some other principles that make conversation successful, moral and pleasant.

Key Words: Discourse Analysis, Conversation analysis, Principles of cooperation.

\section{Literature Review:}

Human beings were created with different intellectual capabilities, insights, mentality, behaviors and approaches. For narrowing down differences \& finding a common ground, they need to have exchange of opinions, logic, dialogue, and various points of view.

English conversation is a type of activity in which two or more persons speak in turns. Conversation is an act of cooperation which is carried out under certain rules. Paul Grice says, "Make your conversational contribution such as is required, at the stage at which it occurs, by the accepted purpose or direction of the talk exchange in which you are engaged"1. During conversation, normally no two particip-ants talk at the same time. One participant does not cut the other participant's speech in the middle but rather waits for his/her turn which is indicated by the other participant's completion of turn. Either the speaker gives signal of finishing his/her turn or the waiting participant tries to take the turn by finding space through body gestures, words or sounds. The desirous participant may show his/her intention for participation in the conversation through his/her facial expressions, shifting of body or by uttering short repeated

*Chairman Department of English, Kohat University of Science \& Technology, Kohat.

Email: s_shojaat_ali@yahoo.com

**HOD, Department of Islamic Studies, Govt: Postgraduate College, Saryab road, Quetta. 
sounds. A participant can signal completion of his/her turn by putting a question or making a stop at the end of a sentence or clause etc. Here we see that while conversing with Allah there is no need of showing restlessness for getting the turn. Allah is all knowing and knows when the other person feels the need of saying something and what actually they want to say before saying something. Allah knows when to stop and when to let others give their statement. Allah gives ample time to others for selfexpression and at the right moment. Allah listens to the whole, whether long or short, e.g. in case of Noah (AS), the complaint about his people is a longer one and Allah gives a patient hearing to his account before giving His statement. Although Allah is supreme and pride suits Him, yet we do not find Him cutting other participant's speech short during conversation.

For making conversation a cooperative activity, Paul Grice $(1975)^{2}$ has put forward four maxims to be observed by the participants of conversation. They are the following:

1) The maxim of quantity, according to which the contribution should be as per the requirement, neither less informative nor more.

2) The maxim of quality, according to which whatever is being stated, there must be adequate evidence to support it, and it must be ensured that the information being provided is not false.

3) The maxim of relevance, according to which irrelevant information has to be abstained from and relevancy has to be ensured.

4) The maxim of manner, according to which the expression should be brief, clear and orderly.

Khalid bin Safwan Al-Tamimi, who remained with two caliphs i.e. Hisham bin Abdul Malik and Omar bin Abdul Aziz, said: 'If a person tells you something you have heard before, or news that you already learned, do not interrupt him or her to exhibit your knowledge to those present. This is a rude and an ill manner.' ${ }^{3}$ Ibrahim bin Al-Junaid said: 'a son was told by his wise father: 'learn the art of listening as you learn the art of speaking. Listening well means maintaining eye contact, allowing the speaker to finish the speech, and restraining yourself from interrupting his speech. ${ }^{4}$

In linguistics, politeness means giving consideration to and showing awareness of another participant's social and emotional sense of self. ${ }^{5}$; every participant in conversation desires the other participants to recognize it and take care of it. Qura' an gives reference to the advice of Luqman to his son directing him to speak in a gentle and soft manner: "...And lower your voice; indeed, the most disagreeable of sounds is the voice of donkeys." We get instructed by Allah that we should talk in a suitable tone. While having conversation with others, the voice of the speaker should be low and pleasant. To talk with a raised voice is against good manners and is disparaging for the other participant in the conversation.

Allah instructs the companions of Mohammad mpbh in Surat Al-Hujurat:

'Oh you who believe! Raise not your voices, above the voice of the Prophet, nor speak aloud to him as you speak aloud to one another,

lest your deeds become vain and you perceive not. ${ }^{7}$ 
Imam Bukhari reported that according to Abdullah bin Al-Zubair, "Since the revelation of this Verse, 'Umar used to speak in such a low tone that the Prophet had to ask him to repeat his statements" 8 . Linguistics guides us that in order to have a successful conversation, the speaker has to take care of another participant's public self-image, named by pragmatics as 'face'. Muhammad MPBH is being reminded by Allah about the importance of his soft and gentle manners:

"And it was by God's grace that thou [O Prophet] didst deal gently with thy followers: for if thou hadst been harsh and hard of heart, they would indeed have broken away from thee."9

For the sake of inviting non-believers to Islam, Allah advises Muhammad MPBH to hold conversation with them in such a way as to begin with common ground between you and them and then proceed to the less common points: "Come to a common word between us and you: that we shall worship none but God...." It It may bring them closer as opposed to beginning with the differences, which closes doors on understanding each other, right from the beginning. Despite acute differences, the decency of speech and the avoidance of abusive language must be maintained. Allah, the glorious, says: "And say to my slaves (i.e. the believers) that they should (only) say those words that are the best." them in a way that is better." 2 Allah forbids believers from back-biting and equals such an act with eating one's brother's flesh. "And do not spy or backbite each other. Would one of you like to eat the flesh of his brother when dead? You would detest it."13 Islam recommends face-saving act. If you order someone to do something and you do not actually wield the social power to do it, then it constitutes a face threatening act. ${ }^{14}$ Islam recommends that although you may wield power, yet you need not threaten another participant's face. Allah teaches us how to deal with those who are adamant, pig-headed, and foolish or those who want to have argument for the sake of argument in the following verse:

"...And when the foolish address them (with bad words) they reply back with 'Salamaa' (peaceful words of gentleness." 15

From this verse of the Qura'an, we get a clear and major characteristic of a Muslim's speech which is that instead of bad words, he reciprocates bad words with words of peace, makes peace with speakers who say such bad words, and refrain from useless conversations with them that lack knowledge and lead only to foolishness. A Muslim abstains from having serious conversation with the foolish, and if he makes a response at all, then it is a response based on gentleness. At another place the same idea is asserted by Allah Almighty in Qura'an in the following way:

"If they pass by some vain speech or play, they pass by it with dignity. "16 Therefore, instead of becoming serious with frivolous and foolish people, a Muslim must refrain from them and excuse himself with gentle words.

\section{Analysis and Discussion: \\ Conversation of Allah with the Satan:}

Allah gave order to Satan to bow before Adam but he refused; Allah could have 
punished him there and then but Allah, instead of using force, granted him freedom to express his view point. Qura'an instead of force recommends dialogue as a source of reforming the opponent and bringing them round to one's view-point. If the argument given by the opponent is forceful then it should be admitted. Qura'an guides us that unjustified use of force is never the solution and Allah despite being the greatest and the all-powerful has used dialogue. Despite Satan's refusal, Allah is showing attentiveness. Successful dialogue requires good listening as it helps understand argument of the other side. We find this manner of conversation being followed by Mohammad MPBH in his conversation and dialogues with his people and adversaries both.

He said: $O$ Iblis! What aileth thee that thou art not among the prostrate?

He said: I am not going to prostrate myself unto a mortal whom Thou hast created out of potter's clay (of black mud altered!)

He said: Then go thou forth from hence, for verily thou art outcast.

And lo! The curse shall be upon thee till the Day of Judgement.

Only when the proof was established, did Allah punish him.

He said: My Lord! Reprieve me till the day when they are raised.

He said: Then lo! Thou art of those reprieved. Till an appointed time. ${ }^{17}$

The first thing that we deduce here as belonging to high manners is to address the other participants with their proper names, even if it be one's adversary.

Despite this all, Allah granted his request for respite even after being proved guilty and sentenced to punishment.

He said: My Lord! Because Thou hast sent me astray, I verily shall adorn the

path of error for them in the earth, and shall mislead them every one

Save such of them as are thy perfectly devoted slaves

He Said: this is a right course incumbent upon Me

Lo !as for My Slaves, thou hast no power over any of them save such of the forward as follow thee. ${ }^{18}$

Question and answer session took place and arguments were given; during conversation Satan took care of the greatness of Allah although he was disobedient and hence had become an enemy and a cursed creature of Allah. Despite this all, the matter was settled through discussion, giving us the lesson that no matter how high may be the differences between the opponents, and whatever may the nature be of Controversy, the best means of solution is discussion.

An underlying assumption in most conversational exchanges seems to be that the Participants are co-operating with each other. This principle, together with four maxims that we expect our conversational partners to obey, was first described by the philosopher Paul Grice. The co-operative principle is stated in the following way: "Make your conversational contribution such as is required, at the stage at which it occurs, by the accepted purpose or direction of the talk exchange in which you are engaged"19. Supporting this principle are four maxims, often called the "Gricean maxims." We also find that the conversation conformed to the maxims of quantity, quality, relation and manner as given by Paul Grice ${ }^{20}$. The talk is extremely concise. There is neither 
anything superfluous nor wanting in the information required to carry on the conversation. There was no room for hearsay, conjectures, and opinions in the conversation and everything was based on truths and facts. Each turn in conversation is characterized by relevancy. The manner of conversation has clarity and order.

\section{Conversation of Allah with Angels:}

There was a complete conversation between Allah and angels; questions were asked and answers given from both sides. About angels Allah says in the Qura'an:

God said: they do not disobey Allah in what He commands them. ${ }^{21}$

So they can neither disobey the commands of Allah nor criticize the decisions of Allah. When Allah said:

God said: And [mention, O Muhammad], when your Lord said to the angels, "Indeed, I will make upon the earth a successive authority." They said, "Will You place upon it one who causes corruption therein and sheds blood, while we declare Your praise and sanctify You?" Allah said, "Indeed, I know that which you do not know." 22

Normally there are various strategies of participation in conversation, some of which appear to be the source of rudeness, such as when a participant cuts in on another ${ }^{23}$. It happens most of the times when the participant who cuts in on another is powerful, disrespectful, or does not consider the views of the other participant as right, appropriate, significant or pleasant. Although Allah is all-powerful and everything is under His perfect control, yet in case of Allah's conversation with Satan and with the angels, we do not find traces of such strategies of cutting in on another.

Allah is the greatest and all the creatures are dependent on Allah, not only for coming into being but also in each second of their existence. Despite this huge disparity in the status of Allah and His angels, Allah shows respect to and appreciation of the opinions of the Angels. We get this guidance from it that while conversing with others, mutual respect should be maintained between the parties and each participant must be provided a chance. Each participant's dignity should be recognized by addressing him/her with respectful words and good manners in order for the conversation to be healthy, beneficial, and positive. On the other hand if the other participant is treated as ignorant or is treated with disparaging and mocking attitude, then the conversation will proceed negatively. Allah the glorious says,

"O you who believe! Let not a group scoff at another group, it may be

that the latter are better than the former" 24

The participants in the conversation follow the principle of cooperation which is that you put in your conversational contribution according to the need of the occasion, to the stage of conversation and to the direction of the conversation ${ }^{25}$. In Qura'an, the holy book of guidance, we see the cooperative principle in operation during all this conversation between Allah and Satan.

The dialogue apparently shows that Allah was asking for the angels' advice whether to create human beings or not and the answer of the angels apparently shows that the angels were objecting to Allah's plan as according to their understanding human 
beings would do damage and do bloodshed on earth. Neither holds ground because Allah neither needs someone's consultation in doing a thing nor the angels have the competence to disobey Allah or to object over Allah's plans. Firstly, Allah was not consulting them but rather informing them of appointment of Adam as vicegerent as ordained. Secondly, here Almighty Allah did a consultation for the sake of educating angels so that they might understand the logic and wisdom behind the appointment of Adam as a vicegerent of Allah on earth. Thirdly, the question of the angles was not a type of rejection of Allah's plan; rather it was a request for knowing the wisdom behind Allah's plan for appointing Adam as the vicegerent. We also understand that here Allah seems to give the impression that the angels were given a chance to give expression of their views against the creation of human beings but later on they came to understand that they were wrong.

However, here what we derive with respect to conversation is that no matter what may be the understanding level of the other party in conversation, they should be offered a chance of self-expression even if they disagree. Even if one, who is powerful and self-sufficient in understanding, is a party in conversation and knows for sure that the other party is wrong, even then one should take them into confidence and give them a complete listening during conversation; whenever one should try to get across an idea it should be done logically, rationally and if possible with facts and demonstration. After the creation of Adam, Allah initially asked the angels to say the names of items but upon their failure when Allah asked the same question of Adam, he gave exact answers. Only after this demonstration did Allah convinced them that He knows what they do not know and therefore $\mathrm{He}$ is right in executing His plan of creating human beings. So decision should be made after talks and during conversation one should not try to suppress the view point of the other party with the help of one's power show and superiority, even if the weaker party's opinion is against one's temperament and understanding.

\section{Allah's Conversation with Ibrahim AS}

When Ibrahim asked Allah in Chapter2, Verse 260: And [mention] when Ibrahim said:

"My Lord, show me how You give life to the dead."26

In response to it, Allah neither kept silent nor snubbed, but rather in a scholarly manner just to let Ibrahim speak out his mind, asked if he did not believe in it: Allah] said: "Have you not believed?"

[He said: "Yes, but [I ask] only that my heart may be satisfied." 27

After this Allah ordered him to slaughter birds and convert them into pieces and spread them over mountains and after that call them in the name of Allah.

[Allah] said, "Take four birds and commit them to yourself [train them to come to your command]. Then [after slaughtering them] put on each hill a portion of them [after mixing up the meet]; then call them - they will come [flying] to you in haste. And know that Allah is Exalted in Might and Wise. ${ }^{28}$

When he did this, the pieces of meat combined, got converted to living birds and answered the call of Ibrahim by coming to him. So again we see the getting across of 
an idea into the mind of the other party of the conversation with solid facts and demonstration. By holding a dialogue with Ibrahim, Allah showed that dialogue can be held with the dearest and favorite friend like Ibrahim, just as it can be held with the rejected and cursed enemy like Satan.

\section{Allah's Conversation with Musa AS}

(Once, Moses was a step ahead in excitement.) Said his Lord, "What has made you hasten from your people, O Moses?" Moses answered, "They are doing fine following my footsteps. I have rushed to You my Lord, so that You may be wellpleased with me." 29

Qualities of patience and tolerance are found displayed in the conversation of Allah with Musa AS. Allah treats the recklessness of Musa with lenity and calmness, without giving outlet to His anger. The quality of tolerance enables a speaker in the conversation to desist from getting angry, nervous, inattentive and interruptive. The same patience and tolerance we see on the part of Allah when talking to His arch enemy, the Satan. When Allah made Musa AS a prophet and was sending him towards the despot Fir'aun, Musa AS asked Allah, if his brother could also be appointed as his supporter Prophet as he himself suffered from stammering in speech as given in the Qura'an:

"And appoint for me a helper from my family,

"Harun (Aaron), my brother; "Increase my strength with him,

"And let him share my task (of conveying Allah's Message and Prophethood),

"That we may glorify You much, "And remember You much. ${ }^{30}$

Although Allah, being all-knowing, knew this weakness of Musa before and Allah also knew in advance which question Musa AS would be asking, and could have appointed his brother before He was asked, yet Allah let him speak out his wish and then Allah did not stand by his earlier injunction but rather conceded what Musa had asked for.

Allah said: "You are granted your request, O Musa (Moses)!

"And indeed We conferred a favour on you another time (before). ${ }^{31}$

Here we get the idea that one should not consider one's word as final but, if one's subordinates' suggestions are worthwhile, then one can accommodate their suggestions and opinions too, to make them feel grateful.

Musa AS made a big request of Allah when he asked for seeing Allah with his eyes so that his belief is increased. Allah neither turned down his request instantly nor reprimanded him but rather in a scholarly manner had conversation with him.

"And when Moses came at Our appointed time and his Lord spoke to him, he said, My Lord, show Yourself to me so that I may look at You. He replied, You cannot see Me, but look at the mountain; if it remains firmly in its place, then only will you see Me. And when his Lord manifested Himself on the mountain, He broke it into pieces and Moses felt down unconscious. And when he recovered, he said, Glory be to You, I turn towards You, and I am the first to believe." 32 Instead of turning down the request as impossible or irrational, Allah made him understand through a relevant, logical, adequate, and understandable demonstration. The result was that Musa AS himself was convinced of the illogicality of his request 
and the impossibility of its being fulfilled and therefore instead asked Allah's forgiveness. Allah can see the facial expressions and knows the internal feelings. So Allah sees them and makes relevant statement or asks relevant question. One thing should be noted that being all-knowing Allah does not put a question in order to know something but for letting the addressee consider the matter in hand, as in case of Musa Allah puts the following question:

"And what is that in your right hand, O Musa (Moses)?" He said: "This is my stick, whereon I lean, and wherewith I beat down branches for my sheep, and wherein I find other uses. "33

Allah knows that he is holding a stick but just to focus the attention of Musa towards it and to drive the point across firmly, Allah puts a question. Secondly when Allah asks Musa what he is holding Musa AS does not answer with the single word 'stick'. Rather Musa AS in his excitement of talking directly to his creator gives a long winded answer. The reply of Musa AS seems to be violating the maxim of quantity and has something more than what is asked as Musa AS goes on the provide the uses and function of the staff too. However, when we analyze it deeply, then it comes out to be following the maxim of relevancy and is based on the spirit of cooperation for having extra information relevant to the question asked. Besides, here the long answer seems quite natural if we keep in consideration the excitement of Musa AS in talking to Allah. Allah listens to the whole with attention and patience. Being all-knowing, Allah does not tell Musa that he knows everything so there is no need of his longwinded justification and explanation.

While sending Musa AS to Fir'aun, Allah teaches us the best code of conduct to be upheld during a conversation. The oft-talked about rule of identifying oneself to the recipient, before discussion on the telephone, finds practical demonstration in the Holy Qura'an. Before talking to Musa AS for the first time, Allah does not start talking without letting Himself known to Musa AS. Allah afteridentifying Himself, introduces Himself before addressing and ordering Musa (AS) as:

Indeed, I am your Lord, so remove your sandals. Indeed, you are in the sacred valley of Tuwa. I have chosen you as a prophet, so listen to what is revealed to you. I am the Unique God, and there is no god apart from I. Worship me alone, and establish prayer so that you may remember Me. The resurrection is sure to come...so that every soul may be recompensed as he strives. ${ }^{34}$

The Gricean maxim of quality demands that we abstain from saying anything which we believe to be doubtful, and for which the evidence with us is inadequate (Yule, 2010). ${ }^{35}$ Allah does not demand compliance on weak foundations of doubt and fear. Allah assures Musa AS of his presence and help when he would be talking to Fir'aun. Similarly, to convince Musa AS first, Allah demonstrates His power before sending Musa AS to the powerful King Fir'aun, so that when he talks to Fir'aun he should talk with strong conviction instead of doubt and hesitation. Allah does a demonstration of his own power in the form of converting his stick into a snake and then back to the stick as go the following verses of the Holy Qura'an: 
(Allah) said: "Cast it down, O Musa (Moses)!"

He cast it down, and behold! It was a snake, moving quickly.

Allah said: "Grasp it, and fear not, we shall return it to its former state,

"And press your (right) hand to your (left) side, it will come forth white (and

shining), without any disease as another sign,

"That We may show you (some) of Our Greater Signs. ${ }^{36}$

Musa AS sees all this with his own eyes so as to speak with full conviction. After this, Allah equips him with various miracles to be shown to Fir'aun and his people as evidence of the reality of his message.

Linguistically politeness is taking care of and not offending the other participant's emotional and social sense of self (Yule, 2010). ${ }^{37}$ Showing politeness to a normal or neutral participant of conversation is a quality of high value. However to show politeness to a culprit who has perpetrated severe type of genocide and atrocities and to a criminal over whom one has complete control is politeness above par. Although Allah knows the history of Fir'aun's cruelties, killings and persecutions yet Allah instructs Musa to talk to him politely. Here we see that Fir'aun's public self -image, called 'face' in pragmatics, is taken care of. In the case of Fir'aun, the attitude and tone of conversation of Allah, instead of being revengeful and punitive, are based on the welfare and goodwill of the other participant of conversation, who is a culprit here. Here Allah also teaches how to run an argumentative type of dialogue and conversation which is based on clash of interests. Allah, instead of sending Musa AS to directly punish Fir'aun for his past cruelties and killings, offers a chance of settling the issue amicably by asking him to set the community of Musa AS free. Allah shows no intention of punishing Fir'aunfor cruelties and killings perpetrated by him in ignorance, but rather wishes his goodwill as visible in the following verses:

"So go to him and say, 'Indeed, we are messengers of your Lord, so send with us the Children of Israel and do not torment them. We have come to you with a sign from your Lord. And peace will be upon he who follows the guidance. Indeed, it has been revealed to us that the punishment will be upon whoever denies and turns away. "38

Before finally destroying Fir'aun and his followers completely and instead of punishing them all of a sudden, Allah first sends seven types of calamities as warnings to then to take their cue. Similarly Allah does not approve of propaganda and does not demand compliance without equipping Musa AS with proofs of his being the messenger of Allah. Therefore, before sending Musa AS to Fir'aun, Allah equips him with some miracles to let Fir'aun believe that it is neither a false message nor of an ordinary person.

\section{Allah's Conversation with Noah AS}

Allah had ordered Noah to seat his family members, the believers and a pair of each animal in his ark before the storm arrived. When the storm overtook all the people, and Noah's son refused to sit in the ark, his fatherly affection overpowered him and asked Allah to save his son as Allah had given his word to save his family members. Allah instead of rebuking him made him understand logically that his son was not 
from his family because he was not from amongst the believers. Therefore Noah should not ask for something the reality of which is not known to him. And Allah said that He advised him not to become one from the ignorant. Upon which Noah AS realized his mistake and ignorance and asked Allah's forgiveness and refuge. Allah does not reprimand without reason or for somebody's lack of knowledge

If you order someone to do something and you do not actually wield the social power to do it, then it constitutes a face threatening act. ${ }^{39}$ ANASAllah has the power to give orders and to be followed blindly. In the above mentioned case of Noah, although Allah is all-powerful, yet Allah does not give direct orders for compliance without any reason and logic. Instead of ordering something directly, Allah shows the logic and the consequences of something when Allah tells someone to do something.

\section{CONCLUSION}

Islam, being a way of life totally in agreement with the nature and temperament of Human beings, is a religion par excellence, from the Creator of the whole universe. Qura' an comprises of all the core rules, regulations, manners and etiquettes of Islam, maintaining of which ensures a distinguished place for a Muslim in his manners, appearance, creed, and character. The guidelines and regulations derived from the Qura'an are the final and the finest ones, are far superior to those of all the previously revealed religions, and are a sure source of peace, well-being and prosperity.Islam, as a religion, was sent by the Almighty Allah to inculcate and establish fine manners and superb etiquettes, besides providing guidelines in other walks of life. Islam, being a complete and perfect code of life, provides guidance regarding conversation and discussion too.

In the Holy Qura'an, we find excellent models of conversations and discussions, in which Allah himself participated and some rules that Allah himself recommended, appreciated or enjoined upon the believers. In these discussions and instructions we find a manifestation of all the best guidelines provided by the discipline of Linguistics regarding conversations.Apart from the rules furnished by linguistics, we find some additional and exquisite rules that make conversation a highly cooperative and successful activity. We find the qualities of identifying and defining oneself to other participant, attentive and full listening to the other or weaker participant, showing flexibility in accepting a subordinate's suggestion if it is useful, resolution of problems through free discussion, consulting with others and giving respect to others' views even if one is self-sufficient intellectually, addressing with name even if an enemy, convincing with proofs and demonstration, offering freedom of expression, showing patience to others, readiness to forgive, consideration of the well-being of the other participant, abstinence from the use of authority, force, and threat, emphasis on logic and rationale for convincing others, restraining from interruption, maintaining politeness and decency in speech, maintaining of secrecy, avoidance of loose and useless talk, face-saving of the other participant, abstinence from lies and exaggera-tion, demonstration instead of pure injunctions, informing of the consequences of the other participant's view-point, adhering to conciseness, relevancy, and brevity, repudiation of hearsay, avoidance of 
discussion with the stubborn, the pigheaded, and the miscreants, reciprocation of bad words with gentle ones, maintaining of moderate voice and tone, refraining from backbiting, and mocking others, calling other names, and considering others inferior.

\section{REFERENCES:}

${ }^{1}$ Grice, H. P. (1975). Logic and Conversation. In P. Cole \& J. Morgan (Eds.) Syntax and semantics Volume 3: Speech acts. New York: Academic Press. p.45

${ }^{2}$ Ibid.

${ }^{3}$ Ghudda, S.A.F.A. Islamic Manners: The Art of Listening: http://www.islaam.com/Article.asp?id=592

${ }^{4}$ Ibid

${ }^{5}$ Yule, G. (2010). The Study of Language. Cambridge University Press.

${ }^{6}$ Luqman: 19

${ }^{7}$ Al-Hujurat: 2,3

${ }^{8}$ Sahih Bukhari, Volume 9, Book 92, \#405, Book: Holding Fast to The Quran and The Sunnah; Page 1534, \#7302

${ }^{9}$ Al-i-Imran: 159

${ }^{10}$ Al-i-Imran: 64

${ }^{11}$ Al-Isra: 53

${ }^{12}$ An-Nahl: 125

${ }^{13}$ Al-Hujurat :12

${ }^{14}$ Yule, G. (2010). The Study of Language. Cambridge University Press.

${ }^{15}$ Al-Furqan: 63

${ }^{16}$ Al-Furqan: 72

${ }^{17}$ Al-Hijr:32-38

${ }^{18}$ Al-Hijr: $39-42$

${ }^{19}$ Grice, H. P. (1975). Logic and Conversation. In P. Cole \& J. Morgan (Eds.) Syntax and semantics Volume 3: Speech acts. New York: Academic Press. p.45

${ }^{20}$ Ibid

${ }^{21}$ At-Tahrim: 6

${ }^{22}$ Al-Baqarah: 30

${ }^{23}$ Yule, G. (2010). The Study of Language. Cambridge University Press.

${ }^{24} \mathrm{Al}$-Hujurat: 11

${ }^{25}$ Grice, H. P. (1975). Logic and Conversation. In P. Cole \& J. Morgan (Eds.) Syntax and semantics Volume 3: Speech acts. New York: Academic Press.

${ }^{26,27,28}$ Al-Baqarah:260

${ }^{29}$ Taa-Haa: 83,84

${ }^{30}$ Taa-Haa:29-34

${ }^{31}$ Taa-Haa:36, 37

${ }^{32}$ Al-A'raf: 143

${ }^{33}$ Taa-Haa: 17,18

${ }^{34}$ Taa-Haa: $12-15$

${ }^{35,37,39}$ Yule, G. (2010). The Study of Language. Cambridge University Press.

${ }^{36}$ Taa-Haa: $18-22$

${ }^{38}$ Taa-Haa:47

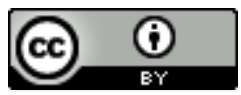

This work is licensed under a Creative Commons Attribution 4.0 International License. 